\title{
FABER POLYNOMIAL COEFFICIENTS FOR GENERALIZED BI-SUBORDINATE FUNCTIONS OF COMPLEX ORDER
}

\author{
Erhan Deniz, Jay M. Jahangiri, Samaneh G. Hamidi and Sibel K. Kina
}

Abstract. In this paper, we obtain the upper bounds for the $n$-th $(n \geqslant 3)$ coefficients for generalized bi-subordinate functions of complex order by using Faber polynomial expansions. The results, which are presented in this paper, would generalize those in related works of several earlier authors.

Mathematics subject classification (2010): Primary 30C45, Secondary 30C80. functions.

Keywords and phrases: Fabel polynomials, analytic, subordinate, convex, starlike, and bi-univalent

\section{REFERENCES}

[1] H. Airault, Remarks on Faber polynomials, Int. Math. Forum 3 (9-12) (2008) 449-456, MR2386197.

[2] H. Airault, A. Bouali, Differential calculus on the Faber polynomials, Bull. Sci. Math. 130 (3) (2006) 179-222, MR2215663.

[3] H. Airault, J. REN, An algebra of differential operators and generating functions on the set of univalent functions, Bull. Sci. Math. 126 (5) (2002) 343-367, MR1914725.

[4] R. M. Ali, S. K. Lee, V. Ravichandran, S. Supramaniam, Coefficient estimates for biunivalent Ma-Minda starlike and convex functions, Appl. Math. Lett. 25 (3) (2012) 344-351, MR2855984.

[5] S. Bulut, Faber polynomial coefficient estimates for a comprehensive subclass of analytic biunivalent functions, C. R. Acad. Sci. Paris, Ser. I 352 (6) (2014) 479-484, MR3210128.

[6] M. ÇAĞLAR, H. ORHAN AND N. YAĞMUR, Coefficient bounds for new subclasses of bi-univalent functions, Filomat 27 (7) (2013), 1165-1171, MR3243989.

[7] E. DENIZ, Certain subclasses of bi-univalent functions satisfying subordinate conditions, J. Class. Anal. 2 (1) (2013) 49-60, MR3322242.

[8] P. L. DUREN, Univalent Functions, Grundlehren der Mathematischen Wissenschaften, vol. 259, Springer, New York, 1983, MR0708494.

[9] G. FABER, Über polynomische Entwickelungen, Math. Ann. 57 (3) (1903) 389-408, MR1511216.

[10] B. A. Frasin, M. K. Aouf, New subclasses of bi-univalent functions, Appl. Math. Lett. 24 (2011) 1569-1573, MR2803711.

[11] S. G. HAMIDI, J. M. JAHANGIRI, Faber polynomial coefficient estimates for analytic bi-close-toconvex functions, C. R. Acad. Sci. Paris, Ser. I 352 (1) (2014) 17-20, MR3150761.

[12] S. G. HAMIDI, J. M. JAHANGIRI, Faber polynomial coefficient estimates for bi-univalent functions defined by subordinations, Bull. Iran. Math. Soc. 41 (5) (2015) 1103-1119, MR3416618.

[13] S. G. HAMId, J. M. JAHANGIRI, Faber polynomial coefficient of bi-subordinate functions, C. R. Acad. Sci. Paris, Ser. I 354 (4), (2016) 365-370, MR3473550.

[14] J. M. JAhANGIRI, S. G. HAMIDI, Coefficient estimates for certain classes of bi-univalent functions, Int. J. Math. Math. Sci. (2013) Article ID 190560, 4 pages, MR3100751.

[15] J. M. Jahangiri, S. G. Hamidi, S. A. Halim, Coefficients of bi-univalent functions with positive real part derivatives, Bull. Malay. Math. Sci. Soc. (2) 37 (2014), no. 3, 633-640, MR3234504.

[16] J. M. JAHANGIRI, S. G. HAMIDI, Faber polynomial coefficient estimates for analytic bi-Bazilevic functions, Mat. Vesnik 67 (2) (2015), 123-129, MR3385795.

[17] J. M. JahangiRi, N. MAGesh, J. YAmini, Fekete-Szego inequalities for classes of bi-starlike and bi-convex functions, Electron. J. Math. Anal. Appl. 3 (1) (2015) 133-140, MR3280637. 
[18] S. Kanas, A. Wisniowska, Conic regions and k-uniform convexity, J. Math. Anal. Appl. 105 (1999) 327-336, MR1690599.

[19] S. S. Kumar, V. Kumar And V. Ravichandran, Estimates for the initial coefficients of biunivalent functions, Tamsui Oxford J. Inform. Math. Sci. 29 (4) (2013) 487-504, MR3363640.

[20] W. C. MA, D. MINDA, A unified treatment of some special classes of univalent functions, Proceedings of the Conference on Complex Analysis (Tianjin, 1992), 157-169, Conf. Proc. Lecture Notes Anal. I, Int. Press, Cambridge, MA, 1994, MR1343506.

[21] V. Ravichandran, Y. PolatoĞLu, M. Bolcal, A. Şen, Certain subclasses of starlike and convex functions of complex order, Hacettepe J. Math. Stat. 34 (2005) 9-15, MR2212704.

[22] H. M. Srivastava, A. K. Mishra, P. Gochhayat, Certain subclasses of analytic and bi-univalent functions, Appl. Math. Lett. 23 (10) (2010) 1188-1192, MR2665593.

[23] H. M. SRIVASTAVA, S. BUlut, M. ÇAĞLAR, N. YAĞMUR, Coefficient estimates for a general subclass of analytic and bi-univalent functions, Filomat 27 (5) (2013) 831-842, MR3186102.

[24] H. M. SRIVAstava, S. S. EKeR, R. M. Ali, Coefficient bounds for a certain class of analytic and bi-univalent functions, Filomat 29 (8) (2015) 1839-1845, MR3403901.

[25] P. ZAPRAWA, On the Fekete-Szegö problem for classes of bi-univalent functions, Bull. Belg. Math. Soc. Simon Stevin 21 (1) (2014) 169-178, MR3178538.

[26] Q.-H. XU, Y.-C. GUI, H. M. SRIVASTAVA, Coefficient estimates for a certain subclass of analytic and bi-univalent functions, Appl. Math. Lett. 25 (2012) 990-994, MR2902367.

[27] Q.-H. XU, H.-G. XIAO, H. M. SRIVASTAVA, A certain general subclass of analytic and bi-univalent functions and associated coefficient estimate problems, Appl. Math. Comput. 218 (2012) 1146111465, MR2943990. 